\title{
ACERCA DE LA CONTRIBUCIÓN MILITAR DE LA JUNTA GENERAL DE LA PROVINCIA DE GUIPÚZCOA A LA GUERRA DE GRANADA EN $1484^{1}$
}

\author{
ON THE MILITARY CONTRIBUTION \\ OF THE PROVINCE OF GUIPUZCOA BOARD \\ TO THE GRANADA WAR IN 1484
}

\begin{abstract}
Resumen: Los guipuzcoanos participaron con sus milicias y hombres armados en la Guerra de Granada auspiciada por los Reyes Católicos, Isabel y Fernando, desde su ascenso al trono de la Corona de Castilla hasta la conquista del reino nazarí en 1492. En este artículo se estudian por una parte las demandas a la Provincia Guipúzcoa de varias embarcaciones con sus respectivas tripulaciones armadas para controlar los accesos a Granada a través del Estrecho de Gibraltar y por otra las diversas respuestas dadas por los procuradores generales de los concejos de la Provincia, reunidos en la Junta General de Usarraga.
\end{abstract}

Palabras clave: Flota militar, armada, Castilla, guerra de Granada, Junta General, Provincia de Guipúzcoa, Hermandades, Reyes Católicos.

\section{ERNESTO GARCÍA FERNÁNDEZ Universidad del País Vasco}

\begin{abstract}
The Guipuzcoans participated with their militias and their armed men in the war against Granada waged by the Catholic Monarchs Isabella and Ferdinand, from their ascension to the throne of the Crown of Castile to the conquest of the Muslim kingdom of Granada in 1492. In this paper we look into how several requests were made from the Province of Guipuzcoa for several ships with their respective armed crews in order to control the different points of access to the Strait of Gibraltar, on the one hand, and, on the other hand, we examine the replies given by the representatives of the Province councils after the Board Meeting at Usarraga.
\end{abstract}

Keywords: fleet, armada, Castile, Granada war, Board Meeting, Province of Guipuzcoa, Brotherhoods, Catholic Monarchs

\section{SUMARIO}

1. Introducción.- 2. Las cartas regias presentadas a la Junta de las Hermandades de la Provincia de Guipúzcoa.- 3. La justificación ideológica de la demanda de naves armadas a los guipuzcoanos con destino a la guerra contra el Islam granadino.- 4. La respuesta dada por los procuradores de la Junta de Usarraga: el intento de sacar partido político de una situación especial.- 5. Valoración final.

${ }^{1}$ Este artículo se ha elaborado en el marco del proyecto de investigación financiado por el Ministerio de Ciencia e Innovación, Proyectos I+D 2008, titulado "Poder, sociedad y fiscalidad en las Merindades de Allende Ebro y La Rioja durante el Reinado de la dinastía Trastámara", cuya referencia es HẠR2008-05841-C02-02, coordinado con otro Proyecto de la Universidad dé Valladolid, Proyecto integrado en la Red Temática Interuniversitaria Arca Comunis. Página web http://arcacomunis.uma.es/index.php 


\section{INTRODUCCIÓN}

La conquista del reino musulmán de Granada fue uno de los principales objetivos de los Reyes Católicos tras su ascenso al trono de la Corona de Castilla en 1474. Si en un primer momento su preocupación más inmediata fue la de acabar con los partidarios de Juana la Beltraneja y los detractores de su política ${ }^{2}$, pronto entre sus líneas de actuación preferentes se halló la presión diplomática y el acoso militar al reino nazarí de Granada ${ }^{3}$. El gasto que supuso este embate iba a ir parejo al incremento de las demandas fiscales con que financiar estas campañas en el conjunto del reino y a la disponibilidad de una armada marítima capaz de bloquear la llegada de contingentes del Norte de África al dicho reino ${ }^{4}$. Al mismo tiempo estas acometidas requirieron todo un sinfín de disposiciones propagandísticas cuyo fin era legitimar ideológicamente la necesidad de una guerra que representaba un goteo permanente para los bolsillos de sus súbditos y para las gentes que debían abandonar sus tierras y sus oficios para dedicarse al delicado, duro y complicado "arte de la milicia".

Las Juntas Generales de la Provincia de Guipúzcoa, a su vez, se dieron cuenta de la importancia representada por la flota vasca en estas disputas periódicas, circunstancia que aprovecharon, en un toma y daca, calculado por sus representantes y los de la Corona, para conseguir propósitos de otro modo, cuando menos, mucho más lejanos y difíciles de lograr. En este rifirrafe no será, por tanto, equivocado recurrir al concepto político de pacto para definir los acuerdos consensuados entre los representantes de la monarquía y los procuradores de la Provincia en $1484^{5}$. El documento anexo

${ }^{2}$ Tarsicio de AzCONA, Isabel la Católica, Madrid, Edit. Sarpe, 1986, 2 vols., M ${ }^{\mathrm{a}}$ Isabel DEL VAL VALDIVIESO, Isabel la Católica y su tiempo, Granada, Universidad de Granada, 2005 y Luis SUÁREZ FERNÁNDEZ, Los Reyes Católicos, Barcelona, Edit. Ariel, 2004.

${ }^{3}$ Véanse las siguientes obras de Miguel Ángel LADERO QUESADA, Castilla y la conquista del reino de Granada. Universidad de Valladolid, 1967; Granada, historia de un país islámico: (1232-1571). Madrid, Edit. Gredos, 1979; Los Reyes Católicos: la Corona y la unidad de España. Edit. Asociación Francisco López de Gómara 1989; Milicia y economía en la guerra de Granada: el cerco de Baza. Universidad de Valladolid, 1964; La guerra de Granada, $1482-$ 1491. Edit. Diputación de Granada, 2002; Las guerras de Granada en el siglo XV. Edit. Ariel. Barcelona, 2002 y como editor La incorporación de Granada a la Corona de Castilla: actas del Symposium conmemorativo del quinto centenario: (Granada, 2 al 5 de diciembre de 1991). Diputación de Granada, 1993.

${ }^{4}$ Para su formación se pidió ayuda igualmente al señorío de Vizcaya (AGS. RGS. Febrero, 1484, fol. 250 y abril, 1484, fol. 35). En la conformación de esta flota se llegó también a contratar embarcaciones genovesas, pues el 16 de abril de 1484 los reyes castellanos otorgaron carta de seguro a favor del genovés Pascual Lomelin, dueño de una carraca que había sido contratada en la armada "contra los moros". Archivo General de Simancas. Registro General del Sello, abril, 1484 , fol. 31 .

${ }^{5}$ Otras armadas con participación de la flota vasca se organizaron posteriormente con fines militares o diplomáticos. Véase I. SZASZADI LEÓN-BORJA, El origen de la armada de Vizcaya (1492-1493): Nuevos datos documentales. "En la España Medieval", 24 (2001), pp. 365-394; J. PÉREZ DE TUDELA BUESO, La Armada de Vizcaya. Acerca de una razón de fuerza y otros argumentos en el acuerdo de Tordesillas. "El tratado de Tordesillas y su proyección". Valladolid, 1973, Vol. I, pp. 33-92; A. LADERO GALÁN, y M.A. LADERO QUESADA Ejércitos y armadas de los Reyes Católicos: algunos presupuestos y cuentas de gastos entre 1493 y 1500 . "Revista de Historia Militar", 92 (2002), M.A. LADERO QUESADA La armada de Flandes: un episodio en la política naval de los Reyes Católicos (1496-1497). Edit. Real Academia de la Historia. Madrid, 
en el apéndice documental es un exponente claro del contractualismo político conformado entre ambas organizaciones del reino de la Corona de Castilla: la administración regia y las Hermandades guipuzcoanas. En este caso, las actividades político-militares iniciadas por los reyes castellanos requirieron, en mayor o menor medida, no tanto de un sistema de aceptación o rechazo de dicha política, cuanto de la discusión del volumen de las supuestas necesidades financieras o armamentísticas demandadas a las gentes de la Provincia de Guipúzcoa.

El resultado final de este debate entre ambas instituciones no podía ser otro, sino la puesta por escrito de las prestaciones ofrecidas por las villas guipuzcoanas y de las compensaciones recibidas por sus pobladores a cambio de tal servicio. En suma, el diálogo acabó en un compromiso recíproco entre dos poderes artificialmente creados en momentos históricos dispares, pero notablemente desiguales. En este sentido el pacto entre hombres libres es la sucesión del desacuerdo previo. Las Hermandades de la Provincia de Guipúzcoa son uno de los dos sujetos activos del pacto, el otro la monarquía. Este convenio es por una parte un síntoma del reconocimiento del poder político del rey sobre sus súbditos y por otra de la organización jerarquizada de las Hermandades guipuzcoanas sobre el conjunto de sus asociados ${ }^{6}$.

De este modo se derivan, al menos, dos lecciones: la primera nos informa que las Hermandades, a través de sus ordenanzas, constatan la validez del contenido de sus estatutos y de la propia institución en el conjunto del Reino, como representación de un colectivo humano que había decidido, con el visto bueno de la monarquía castellana, adoptar unos sistemas de gobierno alternativos al de los Parientes Mayores solariegos rurales guipuzcoanos. La segunda que los Reyes Católicos no ejercieron un poder de carácter absoluto sobre el territorio guipuzcoano, sino que por el contrario estuvieron dispuestos a llegar a acuerdos, pactos y compromisos puntuales, los cuales, sin embargo, no contravenían en última instancia su política de fondo o de largo alcance. Esta estrategia negociadora requirió a la monarquía tener en cuenta la propia realidad social y el sentir específico de los guipuzcoanos en el contexto histórico de los primeros años de la década de los 80 del siglo XV. Como se evidencia en el texto que se incorpora en el apéndice documental los acuerdos alcanzados demuestran la consecución de un provecho concreto para los guipuzcoanos, que apelan de las exigencias de los reyes castellanos para lograr rebajarlas y para obtener condonaciones de penas u objetivos más difícilmente asibles en otras coyunturas.

La negociación entre estos dos poderes del reino de la Corona de Castilla, las Hermandades guipuzcoanas y la administración regia, para

2003 y de este último autor La armada de Vizcaya (1492-1493): Nuevos datos documentales. "En la España Medieval”, 24 (2001), pp. 365-394.

${ }^{6}$ Véase sobre las Hermandades guipuzcoanas las valoraciones de José Ángel LEMA PUEYO, Por los procuradores de los escuderos hijosdalgo: de la Hermandad General a la formación de las Juntas de la Provincia de Guipuzcoa (siglos XIV-XVI), en El triunfo de las elites urbanas guipuzcoanas: nuevos textos par el estudio del gobierno de las villas y de la Provincia (14121539), Donostia-San Sebastián, 2002, pp. 59-113. 
resolver sus discrepancias fue una fórmula fundamental bastante habitual en las relaciones establecidas entre los Reyes Católicos y la Provincia de Guipúzcoa.

\section{LAS CARTAS REGIAS PRESENTADAS \\ A LA JUNTA DE LAS HERMANDADES \\ DE LA PROVINCIA DE GUIPÚZCOA}

Las Hermandades provinciales de Guipúzcoa se gestaron de hecho a finales del siglo XIV, siendo el año 1397 y la villa de Guetaria, en presencia del corregidor Gonzalo Moro, el punto de arranque de una organización política 'destinada' a gobernar y dirigir los asuntos que más preocupaban al conjunto de los vecinos y moradores de las villas y universidades que habitaron el territorio señalado. Sin menospreciar, las ordenanzas de 1397, las elaboradas en 1457 y sobre todo las de 1463 constituyeron los cuadernos de leyes más importantes para la gobernación de unos valles y comarcas contaminados todavía en esas fechas por las disputas banderizas y las diferencias políticas acaecidas en el Reino de Castilla. Usarraga en la Tierra de Vidania y Basarte en los términos de Azcoitia fueron dos de los puntos de encuentro de los procuradores generales de las hermandades guipuzcoanas donde se trataron aquellas cuestiones que más importaron a la Provincia ${ }^{7}$. Regularmente las Juntas particulares de la Provincia, donde se discutían casos específicos que requerían cierta urgencia, se celebraron en Usarraga y Basarte, en la zona central de la Provincia de Guipúzcoa.

A estas asambleas, normalmente presididas por el corregidor de Guipúzcoa $^{8}$, por estos años tenían derecho a asistir procuradores de 25 villas y de las tres alcaldías mayores de la Provincia (Arería, Aiztondo y Sayaz). Estos 28 procuradores se adscribían al grupo de familias más acomodadas de cada uno de estos centros urbanos o comarcas, pues ya en las ordenanzas de 1463 se exigía que fueran "abonados" . Estos representantes de las corporaciones urbanas y de las universidades no podían tener ningún tipo de dependencia respecto a los Parientes Mayores solariegos guipuzcoanos, con quienes el enfrentamiento había alcanzado cotas de rivalidad extremas a mediados del siglo XV. En 1456 Enrique IV desterró a Jimena y Estepona a numerosos Parientes Mayores guipuzcoanos por su actitud conflictiva en relación con las villas de la Provincia, así como ocasionalmente asimismo por su posicionamiento en las luchas de bandos de la Corona de Castilla. No son

\footnotetext{
${ }^{7}$ Véase José Luis ORELla UnZuÉ El origen de las Juntas Generales de Álava, Bizkaia y Guipúzcoa, en "Jornadas sobre Cortes, Juntas y Parlamentos del Pueblo Vasco. Historia y presente. Eusko Ikaskuntza - Sociedad de Estudios Vascos. Cuadernos de Sección. Derecho". San Sebastián, (1989), pp 133-179 y VV. AA. Historia de las Juntas Generales y Diputación Foral de Guipúzcoa, San Sebastián, 1992.

${ }^{8}$ Sebastián INSAUSTI, El corregidor castellano en Guipúzcoa (siglos XV-XVI). "Boletín de la Real Sociedad Bascongada de los Amigos del País" (1975), 31, pp. 3-32.

${ }^{9}$ Elena Barrena OSoro, Ordenanzas de la Hermandad de Guipúzcoa. Documentos (13751463), San Sebastián, 1982.
} 
casuales los cuadernos de Hermandad de 1457 y 1463, inscritos en un contexto de afirmación de las Hermandades guipuzcoanas con el apoyo directo del monarca castellano Enrique IV.

Es cierto que la creación en 1476 de la Hermandad General de Castilla supeditó en gran medida las Hermandades vizcaínas, alavesas y guipuzcoanas a la primera organización hasta su práctica pérdida de funcionalidad y operatividad de $1496^{10}$, si bien como se aprecia en el texto que incorporamos pervivió una clara autonomía en el funcionamiento de cada una de estas últimas. Por otra parte, es sobresaliente señalar que desde mediados del siglo XV se designó escribano fiel de la Provincia al tolosarra Domenjón González de Andía, lo que le daba derecho a asistir a las reuniones de Juntas Generales ordinarias - dos al año- o extraordinarias. Domenjón se convirtió en un personaje clave en Guipúzcoa, llegando a ser igualmente responsable del sello de la Provincia.

Pues bien, el texto adjunto alude a la celebración de unas Juntas Generales en Usarraga, convocadas por el licenciado Diego Rodríguez de Baeza, que tenía poderes expresos para ello por dos cartas emitidas por los Reyes Católicos, Isabel y Fernando. Ambas cartas fechadas, la primera en Vitoria el 13 de diciembre de $1483^{11}$ y la segunda en la misma localidad, el mismo día, pero en 1484, eran una provisión regia dirigida a los "escuderos fijosdalgo de la nuestra noble i leal provincia de Guipúzcoa”, mediante la que se les notifica el apremio que tienen los reyes para aumentar su flota militar en el entorno de Gibraltar y de los puertos del Reino de Granada "para traer a mas presta conclusión la guerra que nos fasemos al regno e moros de Granada". Se trataba de impedir en lo posible su abastecimiento desde el exterior $^{12}$ - paralelamente ese mismo año se llevaron a cabo campañas de hostigamiento en la Vega de Granada y en zonas próximas a Málaga-, y se solicitaba ayuda militar suplementaria a los pobladores guipuzcoanos porque "avemos menester mas navios y mayores y mas gente de la que fasta qui abemos tenido en la dicha nuestra flota y confiando en la lealtad de vosotros y en la avilidad que tiene la gente de la provincia para las cosas de la mar”.

Es evidente, que los productos resultantes de los astilleros guipuzcoanos, sus navíos y su mayor tamaño, eran especialmente apreciados en la Corona de Castilla, a pesar de la importancia de las atarazanas sevillanas

\footnotetext{
${ }^{10}$ J.L. ORELLA UnZUÉ, El origen de las Juntas Generales de Álava, Bizkaia y Guipúzcoa, en "Jornadas sobre Cortes, Juntas y Parlamentos del Pueblo Vasco. Historia y presente", p. 170.

${ }^{11}$ Por otras fuentes de información sabemos de la emisión de otras provisiones regias desde Vitoria a principios del año 1484. M.A. LADERO QUESADA, Castilla y la conquista del Reino de Granada, p. 32.

${ }^{12}$ Desde luego la flota del Estrecho se convirtió en una fuerza militar que sirviera de barrera de contención de las relaciones comerciales con el Reino de Granada y desde este punto de vista sus misiones debían pasar igualmente por la destrucción, si fuera necesario, de los convoyes que se dirigieran a territorio musulmán con mercancías. Se trataba de una política general que perseguía asimismo la llegada de mantenimientos desde el puerto de Cartagena. El 14 de febrero de 1484 los reyes ordenaron a las justicias del reino de Murcia que procedieran contra quienes llevaran desde dicho puerto mantenimientos para tierra de moros (Véase Archivo General de Simancas. Registro General del Sello, febrero, 1484, folio 249).
} 
especializadas en la construcción de galeras ${ }^{13}$. Asimismo la destreza de los marinos vascos en la mar era otro parámetro determinante, según se señala de manera explícita en la carta regia, no sólo por su habilidad sobradamente conocida en el Atlántico y el Mediterráneo para pescar, navegar o comerciar $^{14}$, sino sobre todo por su elevada capacitación profesional en el manejo de las naves y seguramente también por su bravura manifestada en otras ocasiones en las misiones encomendadas por la realeza castellana ${ }^{15}$, como es reconocido por el licenciado "e porque segund la lealtad que esta provinçia tiene en las cosas tocantes a su serviçio non ha seydo ella la postrera e esta provinçia por la graçia de dios abundan en muchos navios e en personas muy guerreras e gentes belicosas e de gran coraçon espeçial en las guerras de la mar...".

Existen noticias sobre la formación de una flota castellana para controlar las zonas de Gibraltar y su periferia desde principios del siglo $\mathrm{XV}^{16}$. De manera más cercana a la cronología en que se centra este estudio está documentado desde el verano de 1482 que varios navíos comandados por Martín Díaz de Mena, Garci López de Arriarán y Charles de Valera se ocupan de controlar el comercio entre Berbería y el Reino de Granada. Todavía en 1488 los mismos capitanes, el guipuzcoano Garci López de Arriarán y Martín Díaz de Mena, bien conocido en la villa de Bilbao, armaron cuatro embarcaciones para cumplir con el cometido estratégico-militar pensado para el Estrecho de Gibraltar. Aún a comienzos de la primera década del siglo XV son citados Garci López de Arriarán y Juan de Lazcano al frente de embarcaciones encargadas de vigilar las aguas del Estrecho de Gibraltar ${ }^{17}$.

Desde luego, también ha sido citada por la historiografía la preparación de una flota castellana en 1484. En agosto de este último año los capitanes García López de Arriarán, Martín Díaz de Mena y Álvaro de Nava,

\footnotetext{
${ }^{13}$ Véase Antonio Collantes de Terán, Sevilla en la Baja Edad Media. La ciudad y sus hombres. Sevilla, 1984, pp. 239-241. Desde la segunda mitad del siglo XV se aprecia un declive de las atarazanas sevillanas y comienza a sustituirse la galera por otras embarcaciones (veleros y naos) consideradas más adecuadas para conformar la flota marítima castellana, que anuncian cambios de rumbo en el sistema de organización y funcionamiento de la armada de Castilla, como ha señalado Eduardo AZNAR VALLEJO, La organización de la flota real de Castilla en el siglo XV, en Manuel GONZÁLEZ JIMENEZ e Isabel MONTES ROMERO-CAMACHO, La Península Ibérica entre el Mediterráneo ye el Atlántico, siglos XIII y XV: ponencias de las V Jornadas HispanoPortuguesas de Historia Medieval, celebradas en Cádiz del 1 al 4 de abril de 2003, Cádiz, Diputación Provincial de Cádiz, 2006, pp. 323-339, en particular las páginas 323-327.

${ }^{14}$ Ernesto GARCÍA FERNÁNDEZ, Los vascos y el mar: su inserción en un espacio comercial europeo en el transcurso de la baja Edad Media, en El abra: ¿Mare Nostrum?. Portugalete y el mar. Actas de las IV Jornadas de Estudios Históricos "Noble Villa de Portugalete", Portugalete (2006), pp. 27-74.

${ }^{15}$ Tres naos de origen vizcaíno participaron en una expedición a Guinea en 1476. Véase Eduardo AZNAR VALLEJO, La expedición de Charles de Valera a Guinea. Precisiones históricas y técnicas, "En la España Medieval", 25 (2002), pp. 404-423.

${ }^{16}$ Véase más en detalle sobre el particular los trabajos de Eduardo AzNAR VALLEJO, La organización de la flota real de Castilla en el siglo XV, ob. cit. y Marinos vascos en la Guerra naval de Andalucía durante el siglo XV, "Itsas Memoria. Revista de Estudios Marítimos del País Vasco", 5 (2006), pp. 41-52.

${ }^{17}$ Véase E. AZNAR VALLEJo, La organización de la flota real de Castilla en el siglo XV, etc., $o b$. cit. p. 332 y del mismo autor Corso y piratería en las relaciones entre Castilla y Marruecos en la Baja Edad Media, "En la España Medieval", 20 (1997), pp. 407-419.
} 
a las órdenes del capitán General, don Álvaro de Mendoza, conde de Castro, gobiernan una flota formada con naves andaluzas, a las que se han sumado naos de Vizcaya y de Guipúzcoa ${ }^{18}$. Guipúzcoa envío 3 naves y fue compensada con la exención del pago de 1.250.000 maravedís que previamente habían solicitado los reyes castellanos para conformar una armada con la que combatir a los turcos ${ }^{19}$.

Es alabada igualmente la lealtad de los guipuzcoanos, empero, los reyes no demandan a los guipuzcoanos, de manera unilateral, una fuerza militar concreta. Por el contrario requieren a los miembros de la Junta que se concuerden con el licenciado Diego Rodríguez de Baeza para que "asentéis y conçerteys el tienpo que los navíos y gente con que nos aveys de servir para la dicha armada". Está claro que esta circunstancia tenía un coste para los guipuzcoanos, así como que afectaba incluso a los negocios y a las empresas individuales o asociativas de los patrones de los barcos. Lo más adecuado era la discusión de estos pormenores con los procuradores de la Junta y la consecución de un acuerdo considerado bueno o, al menos, aceptable para ambas partes: la administración regia y los representantes de la Provincia. La autoridad moral que representaba la monarquía en el conjunto del Reino y la forma de ejercer el poder directamente por los reyes o sus delegados son cuestiones, por tanto, que conviene diseccionar de manera detallada con el objetivo de aprehender la configuración diversa o pareja del tejido socioinstitucional en los distintos territorios y comarcas integrados en la Corona.

La segunda carta, más breve, era una 'carta de creencia', es decir, de acreditación de la figura del licenciado Diego Rodríguez de Baeza, del discurso político que llevaba a las Juntas de la Provincia de Guipúzcoa, en nombre de los Reyes y de la aceptación de las disposiciones por él acordadas con los componentes de la Junta de Usarraga. Ambas cartas, a solicitud del licenciado, fueron leídas a los asistentes a la Junta por Domenjón González de Andía, "escribano de camara del rey e reyna nuestros sennores i su notario publico en todos sus regnos i sennorios e escribano fiel de la noble i leal provincia” de Guipúzcoa. Domenjón murió cinco años después, el 18 de noviembre de 1489 , mientras se celebraba una Junta General en la villa de Zumaya, siendo sepultado en la iglesia de Santa María de Tolosa. Poco antes de su muerte, el 12 de marzo de 1488, había conseguido de los reyes que su hijo Antón González de Andía le sustituyera en el cargo de escribano fiel de la Provincia ${ }^{20}$. Lo cierto es que Domenjón fue desde mediados del siglo XV un hombre fundamental en la Provincia de Guipúzcoa y ahora, en 1484, desempeñó asimismo una labor de intermediación de gran relevancia.

\footnotetext{
${ }^{18}$ Archivo General de Simancas. Registro General del Sello, diciembre de 1483, folio 106 febrero de 1484, folio 250 y marzo de 1484, folio 13.

${ }^{19}$ Véase al respecto la publicación de la tesis doctoral de M.A. LADERo QUESADA, Castilla y la conquista del Reino de Granada...etc. pp. 146-151 y E. AZNAR VALLEJO, La organización de la flota real de Castilla en el siglo XV, ob. cit., p. 331.

${ }^{20}$ J.L. ORELla UnZUÉ, Estudio iushistórico de las Juntas de Gipuzkoa hasta 1550, VV. AA. Las Juntas en la conformación de Gipuzkoa hasta 1550, San Sebastián, 1995, pp. 143-258 (en particular, pp. 155-156).
} 


\section{LA JUSTIFICACIÓN IDEOLÓGICA \\ DE LA DEMANDA DE NAVES ARMADAS A LOS GUIPUZCOANOS CON DESTINO A LA GUERRA CONTRA EL ISLAM GRANADINO}

El sostenimiento de una guerra contra un enemigo como el reino nazarí de Granada fue considerado una buena causa para los Reyes Católicos, Isabel y Fernando, en la que descansó la solicitud de hombres, barcos y dinero con los que se quiso contribuir a desestabilizar y a derrotar a los musulmanes de la Península Ibérica recogidos globalmente por estos años en el reino de Granada. Ahora bien, esta lucha casi permanente entre los "cristianos castellanos" y los "musulmanes nazaríes" se cimentaba en motivos de calado político, cultural y religioso que no pasaron inadvertidos en la época ${ }^{21}$, pero que sobre todo fueron puestos sobre las cartas presentadas y leídas a los procuradores de la Provincia de Guipúzcoa. La justificación ideológica de esta violencia institucionalizada ${ }^{22}$ era un requisito "sine qua non" de unas guerras que además de un medio para conseguir una paz forzada se constituyeron en un fin propagandístico en sí mismas.

El licenciado Diego Rodríguez de Baeza, como representante de los Reyes Católicos, esgrimió una serie de argumentos, que analizaré en el desarrollo de este epígrafe. Los razonamientos expresados, sin ninguna duda, están mezclados con ingredientes credenciales, porque en verdad se siente el discurso sostenido; con valores ideológico-políticos, pues se conecta el reinado de los Reyes Católicos con un pasado muy remoto y con factores claramente propagandísticos, ya que, no en vano, se trata de convencer a los receptores del mensaje de su validez absoluta para conseguir con la mayor facilidad posible el propósito de formar una armada en Guipúzcoa, que se dirigirá a las fronteras marítimas del reino granadino. En el contexto que se lleva a efecto esta solicitud de ayuda militar estas ideas circularon en los ámbitos culturales de las elites del Reino y en otros más populares.

En esta ocasión afortunadamente se concretan una serie de puntos que posibilitan al historiador hacerse una idea bastante cabal de lo que se estaba fraguando en la Corte. De forma meridiana, salen a la luz directrices varias, asumidas básicamente desde la Corte y su entorno, que permiten observar un relativo sometimiento de los ideales espirituales a los temporales, bajo la apariencia precisamente de todo lo contrario. El poder temporal se nutre ideológicamente de forma palpable de criterios supuestamente provenientes de los ámbitos religioso y eclesiástico. La lectura que se hace de determinados acontecimientos políticos así parece demostrarlo. "Regnum" y "sacerdotium",

${ }^{21}$ Véanse los trabajos de Ana Isabel CARRASCO MANCHADO, Propaganda política en los panegíricos poéticos de los Reyes Católicos: Una aproximación, "Ánuario de Estudios Medievales", 25 (1995), pp. 517-543 y José Manuel NIETO SORIA, Apología y propaganda de la realeza en los cancioneros castellanos del siglo XV. Diseño literario de un modelo político, "En la España Medieval", 11 (1988), pp. 185-222.

${ }^{22}$ Francisco GARCíA FITZ, Edad Media, guerra e ideología: justificaciones jurídicas y religiosas, Madrid, Edit. Sílex, 2003. 
tan unidos en numerosas cuestiones ${ }^{23}$, se intercambian funciones e incluso se puede obtener la impresión de que en más de una ocasión el primero usurpa en ocasiones el terreno específico del segundo. Entran en juego también, desde el punto de vista de la óptica política cristiano-católica, asuntos relacionados con conceptos concernientes al significado que se da a la guerra justa, a la guerra santa, a la unidad de España o con la manera en que se caracteriza al enemigo, que no es otro lógicamente en este caso que el musulmán.

José Manuel Nieto Soria no ha dudado en calificar de "religiosidad política" las actitudes adoptadas desde los aparatos administrativos de la administración regia: Este historiador ha afirmado lo siguiente: "A partir del conocimiento de las imágenes de inspiración teológica que se manejaron en la Castilla bajomedieval con respecto a la realeza, es factible considerar la posibilidad de que éstas dieran lugar a lo que podría calificarse como de 'religiosidad política' o, como otros han preferido, de mística regia. Bajo este concepto de 'religiosidad política' se puede entender todo un conjunto de creencias de significación religiosa y de proyección política, que aplicadas, mediante el uso de diversas imágenes, a una institución política concreta, otorga a ésta connotaciones de indudable valor religioso que incluso pueden llegar a justificar ciertas formas específicas de culto o devoción" ${ }^{24}$.

El discurso del Licenciado Diego Rodríguez de Baeza no tiene ningún impedimento en reproducir este tipo de insinuaciones al afirmar que la llegada al trono de Isabel y Fernando fue querida por Dios "despues que a dios nuestro sennor plugo que ellos veniesen a la subçesion destos regnos", que la tranquilidad alcanzada, el final de males anteriores y la reimplantación de la justicia entre los "tres estados" en el conjunto del Reino fue porque Dios lo quiso y que la conquista del reino de Granada era un designio encomendado por Dios a los Reyes Católicos. El texto es sumamente expresivo sobre el particular: “...como despues que la divina clemençia plugo dar el tal sosiego quiso conbidar a sus altezas a que mas prestamente se moviesen a tomar esta tan sancta e justa enpresa de conquistar el regno de Granada".

En este mismo sentido, se toma en consideración como señales emergentes de carácter profético la conquista de Alhama por las tropas

${ }^{23} \mathrm{~A}$ este respecto se ha señalado los intentos por recuperar la idea de una "República cristiana", lo que comportaba la unión del "Imperium" y el "Sacerdotium". Véase J.M. NIETO SORIA, Iglesia y autoritarismo regio en la Castilla de los descubrimientos, en M. GONZÁLEZ JIMÉNEZ (editor) La Península Iberica en la era de los descubrimientos (1391-1492), "Actas III Jornadas Hispano-Portuguesas de Historia Medieval. Sevilla 25-30 de Noviembre 1991". Sevilla, 1994-1995, vol. I, pp. 643-658.

${ }^{24}$ J.M. NIETO SORIA, Fundamentos ideológicos del poder real en Castilla (siglos XIII-XVI), Madrid, Eudema S.A., 1988, p. 99. Véase asimismo J.M. NIETO SORIA (director), Orígenes de la monarquía hispánica: propaganda y legitimación (ca. 1400-1520), Madrid, Edit. Dykinson, 1999. 
cristianas, la prisión del rey de Granada y la toma de $\operatorname{Sahara}^{25}$. El párrafo que a continuación añado es claro:

\begin{abstract}
...por ynçitaçion e amonestaçion divina porque luego ante todas cosas nuestro sennor quiso i permitio que la çiudad de Alama fuese tomada en grande solaçion i quebrantamiento de los dichos moros de lo qual ha subçedido otras muchas e grandes vitorias asy de la presyon del rey de Granada commo de la toma de Sara e otras cosas muy señaladas que han acaesçido donde paresçe que dios muestra aver gana que los dichos moros sean asolados e destruydos e el dicho regno de Granada sea redusido a su sancta fe catolica e ayuntado a estos sus regnos commo antigoamente lo era antes que Espanna fuese destruyda enbian os a decir que a causa de lo suso dicho tiene muy gran gana de conquistar el dicho regno por lo atraer a la union e religion xriptiana non por codiçia nin anbiçion de ensennorear nin atraer asy nin a su subgeçion el dicho regno salvo por serviçio de dios prinçipalmente e acresçentamiento de su sancta fe....
\end{abstract}

Es palpable que el licenciado presenta a los Reyes Católicos, como los verdaderos abanderados y paladines de Dios en la Tierra, en esa descarnada disputa religiosa con los musulmanes. Esta idea arranca de la vigencia del providencialismo político ya propuesto por los Santos Padres de la Iglesia y con cuya idea se comulga a comienzos de la década de los 80 del siglo XV. De este modo, Isabel y Fernando, pueden ser contemplados como "reyes cristianísimos" 26 , típico de la propia naturaleza de donde proviene el poder de los reyes cristianos en la Edad Media: Dios ${ }^{27}$.

Desde esta perspectiva son reflejados como fieles a los mandamientos de las instancias más elevadas de las jerarquías eclesiásticas, al mismo tiempo que como garantes de su cumplimiento hasta extremos que a veces pueden tener relación, más con su interpretación personal de los mismos que con la obediencia debida. En todo caso, la imagen mesiánica y salvadora de los Reyes Católicos para con sus súbditos y el conjunto de la cristiandad, recogida en los ambientes literarios y culturales de la época, forma parte de la bisagra propagandística de la Corte y de quienes les apoyaron, como ha puesto de relieve José Manuel Nieto Soria ${ }^{28}$.

\footnotetext{
${ }^{25}$ Entre finales de febrero y principios de marzo de 1482 . Don Rodrigo Ponce de León, marqués de Cádiz y otros nobles andaluces tọmaron dicha población, ubicada en la Vega de Granada a unas 10 leguas de la capital del reino nazarí, tan sólo a unos 55 kilómetros. Abu' Abdallah Muhammad ben Alí (Boabdil), hijo de Abu-l-Hassan Alí (Muley Hacén) fue capturado el 21 de abril de 1483 por las tropas del Conde de Cabra y el alcaide de los Donceles, siendo conducido hasta Lucena. Zahara, localidad conquistada por Fernando de Antequera, fue recuperada por los musulmanes el 27 de diciembre de 1482 y reocupada por los cristianos el 26 de octubre de 1483. Véase M.A. LADERO QUESADA, Castilla y la conquista del Reino de Granada, pp. 20-31 y del mismo autor Las Guerras de Granada en el siglo XV, pp. 134-142.

${ }^{26}$ Será unos años después de la conquista de Granada, de la expulsión de los judíos de las Coronas de Castilla y de Aragón, así como de la llegada de Cristóbal Colón a América, cuando el Papa Alejandro VI les dispense por escrito a los monarcas Isabel y Fernando, el 17 de diciembre de 1496, el título honorífico de "Reyes Católicos", aunque dicha Bula se hábía estado fraguandos desde varios años antes.

${ }^{27}$ Ernst H. KANTOROWICZ, Los dos cuerpos del rey. Un estudio de teología política medieval, Madrid, Edit. Alianza Editorial, 1985, pp. 53 y siguientes.

${ }^{28}$ J.M. NiETo SoRIA, Fundamentos ideológicos del poder real en Castilla...etc. pp. 73-75.
} 
Este discurso, del mismo modo que aconteció en los reinados precedentes, reivindica un goticismo absoluto al sostener que el Reino de Granada "fue del sennorio de Espanna poseydo por reyes godos catolicos prinçipes predeçesores de sus reales sennorios". De este modo aflora con fuerza ese espíritu de reconquista, por motivos asimismo religiosos, de unos lugares que en otro tiempo fueron españoles y católicos "donde por luengos tienpos de continuo fue çelebrado el culto divino lo qual todo fue y esta agora profanado e ensusiado de los moros enemigos de nuestra sancta fe catolica donde por ellos es llamado y honrrado el nonbre del malvado mahomad en menospreçio de nuestro salvador ihesu Xripto e de su sancta fe" ${ }^{29}$.

La enemistad manifestada contra los musulmanes y su profeta Mahoma, a quien se atribuye el calificativo de malvado, es otro elemento de carácter provocativo lanzado a un auditorio cristiano católico. Se insiste en que se trata de una "sancta empresa", a llevar a cabo ahora en una coyuntura más favorable desde el punto de vista político, debido a la misericordia divina. Esta acepción de "guerra santa" estaba acorde con la visión de estas campañas desde la susceptibilidad de ser evaluadas como unas auténticas cruzadas contra el infiel ${ }^{30}$. En esta evaluación, al menos en el plano teórico, lo sagrado santificaba lo profano resultando de todo ello una especie de exaltación mística de la guerra ${ }^{31}$. Si damos por sentada la existencia de una fe sincera de los creyentes cristianos, la muerte alcanzaba en estas circunstancias para estas gentes un significado de carácter martirial de unas proporciones psicosociológicas difíciles de medir. Los musulmanes tampoco se quedaron al margen de este tipo de representaciones y significaciones ideológicas ${ }^{32}$.

\section{LA RESPUESTA DADA \\ POR LOS PROCURADORES DE LA JUNTA DE USARRAGA: \\ EL INTENTO DE SACAR PARTIDO POLÍTICO DE UNA SITUACIÓN ESPECIAL}

Lo cierto es que el licenciado Diego Rodríguez de Baeza solicitó a los procuradores de la Provincia de Guipúzcoa, en nombre de los reyes, la entrega de 5 naos bien armadas con artillería y 650 hombres, 250 en un navío

\footnotetext{
${ }^{29}$ Véase en este sentido el libro de M.A. LADERo Quesada, Los Reyes Católicos: la Corona y la unidad de España. Edit. Asociación Francisco Lopez de Gómara. Madrid, 1989, así como el estudio de los orígenes ideológico-políticos de la reconquista en el artículo de María Isabel PÉREZ DE TUDELA, La consideración de la guerra y el uso de la violencia en la España medieval, "En la España Medieval", 30 (2007), pp. 9-25.

${ }^{30}$ Álvaro FERNÁNDEZ DE CÓRDOVA MIRALles, Imagen de los Reyes Católicos en la Roma pontificia, "En la España Medieval", 28 (2005), pp. 259-354. Véase sobre el origen y desarrollo del concepto de cruzada la obra de Jean FLORI, La guerra santa: la formacion de la idea de cruzada en el Occidente cristiano, Granada, 2003.

31 "Las cruzadas, como los diezmos, el Sacro Imperio y la Inquisición, fueron el rasgo característico de una cristiandad en la que las realidades temporales y las sagradas se contaminaban, al sostenerse mutuamente, según necesidades provisionales", ha afirmado Evangelista VILANOVA, Una manipulación de la teología de la paz: las cruzadas medievales, "Ilu. Revista de Ciencias de las Religiones" (2001), pp. 169-173.

${ }^{32}$ Jean FloRI, Guerra Santa, yihad, cruzada: violencia y religión en el cristianismo y el islam, Granada, 2004.
} 
grande y 100 en cada uno de las cuatro naos restantes, con el propósito de controlar la zona del Estrecho de Gibraltar. Se describe en el texto que le entreguen:

\begin{abstract}
un navio grande de doscientos e çinquenta toneles e con quatro pequennos de cada çient toneles e para el grande que dedes doscientos e çinquenta onbres con su artelleria de guerra i en los otros quatro cada çient onbres asy mismo guarnidos e proveidos a vuestra costa por siete meses los quales comiençen desde primero dia de março deste anno fasta en fyn de setienbre para que esten en el estrecho de Givraltar fasiendo guerra a los moros lo qual confian sus altesas que la provinçia sy fara e conplira commo buenos e leales vasallos espeçialmente para tan sancta e justa tornada e disen sus altezas que aqueste serviçio non lo enviar a demandar a fyn de fatigaros salvo por el caso ser de tal calidad e tan justo e nesçesario por ende que bos ruega e manda que lo asy fagays segund la cofiança de vosotros tiene lo qual todo el dicho liçençiado dixo que desia a los dichos procuradores por virtud de la creençia que de sus reales sennorias traya.
\end{abstract}

Los Junteros guipuzcoanos comprendieron de inmediato que éste era un buen momento para anular algunas contrapartidas que afectaban de manera negativa a sus intereses. A cambio de la participación y del elevado coste de la empresa se pretendió conseguir otro tipo de compensaciones. En esta línea pusieron sobre la mesa de la negociación, porque así es citado en el texto este intercambio de pareceres en varias ocasiones, un elenco de reclamaciones al Licenciado Diego Rodríguez de Baeza, cuyas competencias eran claramente más reducidas de lo que se presuponía en las dos cartas presentadas a la asamblea de procuradores. Por supuesto los junteros manifestaron su obediencia a las cartas que les habían sido presentadas, pero en lo que se refiere a su cumplimiento iniciaron todo un proceso formal tendente a rebajar las exigencias del licenciado ${ }^{33}$.

En primer lugar, le solicitaron que abandonara la reunión con el fin de discutir entre ellos cuáles eran los procedimientos a seguir. Posteriormente fue llamado de nuevo don Diego Rodríguez de Baeza, a quien le comunicaron, a través de Domenjón González de Andía, que no podían tomar decisión alguna sin consultar previamente con sus respectivos concejos, porque cuando fueron convocados a la Junta de Usarraga no se les notificó el contenido específico de la convocatoria "por ende que le rogavan que por quanto cumplía asy a serviçio de dios nuestro señor e de los dichos rey e reyna nuestros sennores e al byen desta negociación que los dichos conçejos fuesen consultados". Al mismo tiempo aprovecharon esta reunión para transmitirle al licenciado algunas quejas y le pidieron que contribuyera a su resolución mediante su comunicación en la Corte. Pretenden que el fiscal retire sus cargos contra diferentes personas guipuzcoanas acusadas de ser usureras,

\footnotetext{
${ }^{33}$ Véase Benjamín GONZÁLEZ ALONSO, La fórmula 'obedézcase pero no se cumpla' en el Derecho Castellano de la Baja Edad Media, "Anuario de Historia del Derecho Español", L (1980), pp. 469-487 y R. GÓMEZ RIVERO, La fórmula 'obedecer y no cumplir' en el País Vasco (1452-1526), en El Pueblo Vasco en el Renacimiento (1491-1521) "Actas del Simposio celebrado en la Universidad de Deusto (San Sebastián) con motivo del ${ }^{\circ}$ ' Centenario del nacimiento de Ignacio de Loyola (1-5 Octubre 1990)". Bilbao, 1994, pp. 449-464.
} 
reclaman una carta regia que les permita importar cereal desde Andalucía, por la carestía existente en el territorio y para rebajar de este modo los elevados precios del pan - una fanega de pan costaba un florín- y solicitan la liberación de presos tomados por los navarros a causa de los puercos que les había arrebatado el corregidor de Guipúzcoa, don Juan de Sepúlveda.

El Licenciado accedió, no de buen grado, a la dilación solicitada "commo quier que a el se le fasia grave aver de esperar por la respuesta de los conçejos", pero finalmente les dio plazo hasta después de la fiesta de Reyes, señalándoles respecto a las quejas presentadas que no le cabía ninguna duda de que "bien creya...que agravio ninguno non les seria fecho a la dicha provincia e seyendo sus altesas certificados de lo tal que ellos le remediarían commo cunple a su serviçio e al bien de la dicha provincia". En cualquier caso los procuradores junteros aparecen actuando como auténticos representantes de los concejos, no desean tomar decisiones por su cuenta que pudieran arrastrar problemas con sus vecinos en sus respectivas localidades, pero además ponen un primer freno a las demandas del delegado regio a través de estos mecanismos dilatorios.

El 7 de enero de 1484 se reúnen de nuevo en la Junta de Usarraga y el licenciado Diego Rodríguez de Baeza les transmite la respuesta que por escrito le había llegado de la Corte en relación con las quejas expresadas el 3 de enero por los procuradores. El doctor Alcocer, miembro del Consejo del rey, tras considerar las alegaciones de los junteros respondió lo siguiente: que la Provincia arme cuatro naos con cuatrocientos hombres, dos de las cuales las costeen de forma exclusiva quienes habían sido considerado usureros, jurando que nunca más incurrirán "en este pecado"; que soliciten a sus altezas permiso para traer pan de otras partes, pues "a sus altezas plase de les mandar dar alguna saca razonable" y que respecto a los apresados por los navarros que se inicien los trámites oportunos para estudiar y resolver este conflicto. Una vez escuchada por los junteros la carta leída le solicitaron que les diera licencia para "platicar en el dicho negoçio e que para mannana jueves en otra junta darian la respuesta e el dicho licenciado dixo que le plasia”.

Lo sorprendente del caso es que, Lope Martínez de Olaberria, vecino de la villa de Segura y representante de los procuradores, nuevamente pidió al licenciado permiso para reunirse de nuevo con los concejos de donde procedían, pues había opiniones diversas entre ellos, y que tendrían una respuesta definitiva para el lunes siguiente. El licenciado no salió de su asombro, aunque lo consintió, cuando afirmó lo siguiente:

que se maravillava mucho de los sennores procuradores que estavan juntos
averle de dar tal respuesta a cabo de tanto tienpo e commo quiera que otros
onvres principales obiese en la provincia los que allí estaban eran de los
mas principales e que pues ellos veyan la demanda ser tanto justa y sancta
e catolica y en el caso mas favorable que en el derecho avia por razon del
qual non solamente los bienes de los subditos mas de las iglesias se podrian
tomar e enajenar e aquesto respondia a fyn de dilatar e non dar conclusión
en el negoçio non mirando las cosas que sus altesas fasian e miravan a
favor desta provincia mas que de ninguna çibdad nin provincia destos
Regnos.

ANUARIO DE ESTUdIOS MEDIEVALES (AEM), 40/2,julio-diciembre 2010, pp. 617-642. ISSN 0066-5061 
Este fue el motivo de que amenazara con marcharse de la Provincia, alegando que ya había transcurrido el plazo concedido por sus altezas, más de 20 días, para llevar a cabo la negociación y de que propusiera a varios procuradores para que trataran directamente el asunto "con sus reales sennorias" acudiendo a la Corte antes de nueve días ${ }^{34}$. Al fin y al cabo, esta amenaza no la puso en práctica y se celebró una nueva junta el 13 de enero de 1484, donde se hizo evidente la división de opiniones entre los procuradores, algunos de los cuales no querían consentir en la formación de la armada solicitada por los reyes, si no se les pagaba el salario a los componentes de la misma. Esta circunstancia fue utilizada por el licenciado Diego Rodríguez de Baeza para solicitar que cada uno de los procuradores emitiera su voto favorable o desfavorable, aunque aquéllos lograron evitar dicha votación juntándose para llegar a un acuerdo común. La solución arbitrada por el conjunto de los junteros le fue transmitida al licenciado por Domenjón González de Andía. El objetivo no era otro sino el de aminorar las exigencias de la Corona y para ello argumentaron los "grandes servicios" ofrecidos por la Provincia a la monarquía castellana en los años inmediatamente anteriores.

La Provincia de Guipúzcoa aceptaba servir a sus altezas con dos navíos armados con su respectiva artillería, pero es de sumo interés destacar que expuso previamente ante Diego Rodríguez de Baeza una serie de condiciones "e esto seyendoles otorgado i conplido que serviran a sus altezas". Las estipulaciones recogidas en el cuadro adjunto manifiestan a las claras que se está en presencia de una negociación nada fácil entre el delegado de la monarquía y los procuradores guipuzcoanos. Se persigue, por tanto, la consecución de un acuerdo entre ambas partes, una renegociación de las exigencias de la Corona, en suma, un pacto entre instituciones diferentes jerárquicamente asimétricas, las Hermandades de la Provincia y la administración regia. En ningún momento, los procuradores de la Junta de Usarraga negaron la ayuda militar solicitada por la Corona, pero ya en un primer momento consiguieron que el número de embarcaciones y de hombres exigido a la Provincia fuera menor, posteriormente hicieron recaer el coste de dos naos en aquellas personas guipuzcoanas manifiestamente consideradas usureras por los tribunales de justicia, pero además quisieron obtener otro tipo de contrapartidas y exenciones.

\footnotetext{
${ }^{34}$ Juan Sánchez de Elduayen, alcalde de la Provincia, Martín Sánchez de Estiro, procurador de San Sebastián, el bachiller Iturraza, alcalde de Tolosa, Iñigo Sánchez de Goyaz, vecino de Azpeitia, Juan Sánchez de Zumeta, procurador de Azcoitia, Lope Fernández de Zumaya, procurador de Zumaya y Juan de Ugarte, procurador de Villafranca.
} 


\section{CONDICIONES DE LOS PROCURADORES}

\section{DE LA JUNTA DE LA PROVINCIA DE GUIPÚZCOA}

\section{EL 13 DE ENERO DE 1484 PARA ACEPTAR LAS DEMANDAS DE LA CORONA}

1. Que se anule la solicitud de 1.200.000 maravedís que Alonso de Quintanilla reclama para costear una armada contra los turcos.

2. Que el fiscal actúe contra los presuntos usureros de la Provincia tan sólo si hubiera querellante y no a instancia movida personalmente por él.

3. Que se permita a la Provincia traer cereal por tierra o mar para elaborar pan de cualquier lugar de sus reinos.

4. Que los reyes intervengan lo antes posible en el asunto de los presos y gastos que se les ha ocasionado en tiempos del corregidor Juan de Sepúlveda, a causa de las diferencias entre navarros y guipuzcoanos por el apresamiento de diversos puercos.

5. Que los guipuzcoanos puedan entrar en todos los puertos de los reinos de la Corona y estén exentos de las nuevas imposiciones que les exigen.

6. Que se permita la libertad de movimientos de las embarcaciones de los guipuzcoanos en todos los puertos, incluidos los privados.

7. Que en el caso de esta campaña se provea de pan a quienes acudan a dicha armada durante todo el tiempo que dure su cometido.

Lógicamente esta actitud críticamente reflexiva de los procuradores de la Junta de Usarraga ante las minuciosamente justificadas demandas de la Corona exigió de aquellos una revalorización y ensalzamiento de los servicios prestados, en otras coyunturas especialmente críticas, a los Reyes Católicos. En este contexto sacaron a la palestra del discurso institucional su contribución en los cercos de Burgos y de Toro, su papel desempeñado en la defensa de Fuenterrabía, ante el asedio a que fue sometida por los franceses, así como los gastos ocasionados en estos eventos y las muertes padecidas a consecuencia de estos enfrentamientos, en particular en el caso de Fuenterrabía. Insistieron en la carestía de la vida por la ausencia de cereal y cómo no resaltaron "asy mesmo las exenciones e franquesas e libertades que esta provincia tiene...como de otras cosas que pudieran justamente escusar de non faser el dicho serviçio". Asumen, da la apariencia pese a todo, su participación en esta empresa alegando motivos políticos, su lealtad a la Corona y razones ideológico-religiosas "porque esta negociación es de tal calidad que todos los católicos e fieles xristianos son obligados a seguir tan justa enpresa".

Ahora bien, esta colaboración está rodeada de una serie de requisitos que reducen su concurrencia y ponen en jaque aparentemente la propia cooperación naval de los guipuzcoanos en el control del Estrecho de Gibraltar "non con tantos navíos commo les son demandados porque la dicha provincia non lo puede conplir pero que servira con dos navíos cada uno de çient onvres por el tienpo contenido en el mandamiento de sus altezas con tanto quel dicho licenciado en nonbre de sus reales sennorias les otorgue las cosas seguientes e les envien confirmados de sus altezas de todo ello". 
El licenciado Diego Rodríguez de Baeza tomó acta de lo solicitado por los procuradores de la Junta de Usarraga notificándoles que transmitiría todos sus deseos a los reyes, los cuales "remediarian en ello segund biesen cumplía a su serviçio", pidiendo al escribano fiel de la Provincia, don Domenjón González de Andía, que le diera testimonio de lo acontecido.

\section{VALORACIÓN FINAL}

Yo destacaría cuatro argumentos o consecuencias principales derivados o relacionados de alguna manera con la realización de este artículo. El primero alude de forma directa a que el análisis del documento escrito estudiado, en el contexto histórico en que se produjo su redacción, ha permitido conocer cuáles eran los procedimientos más habituales de relación entre la administración monárquica castellana y los procuradores de la Provincia de Guipúzcoa. Los mecanismos de emisión, recepción, aceptación, discusión y respuesta a los mensajes regios son ingredientes activos en los sistemas de funcionamiento administrativo de la época.

El segundo destaca el hecho de valorar el descubrimiento de la celebración de una Junta particular en Usarraga durante los primeros días del mes de enero del año 1484, no recogida en otros elencos bibliográficos por historiadores muy interesados en anotar todas las asambleas políticas provinciales guipuzcoanas de las que se tiene conocimiento fehaciente en el transcurso de la historia. Afortunadamente la solicitud de un traslado documental por parte del procurador del concejo de la villa de Mondragón ha contribuido a este hallazgo documental en un proceso judicial conservado en el Archivo de la Real Chancillería de Valladolid. Domenjón González de Andía, escribano fiel de la "noble e leal" Provincia, escribió estos folios el 14 de enero de 1484 "a ruego e pedimiento del conçejo de la dicha villa de Mondragón este testimonio fise escribir el qual va escripto en estas seys fojas de pliego de papel e en cada foja va una rubrica de los de mi nonbre".

El tercero, intrínsicamente unido a la primera de las argumentaciones, tal vez uno de los puntales más relevantes del edificio literario construido, porque ha sido útil para certificar una vez más la existencia de negociaciones de carácter bilateral entre la monarquía y la Provincia de Guipúzcoa, a pesar de la elevada carga ideológica y propagandística que acompañaron a las solicitudes regias. Aunque este diálogo a dos bandas fuera disimétrico y desigual desde un punto de vista jerárquico, no por ello se deja de estar en presencia de pactos y acuerdos finalmente consensuados entre la monarquía castellana y las Hermandades guipuzcoanas, representadas por sus procuradores.

Y el cuarto, saca a la luz el importante sentimiento corporativo de las hermandades guipuzcoanas y el interés sobre todo de los procuradores de la Provincia por ofrecer una respuesta común frente a la crispación que podría generar una división de opiniones manifiesta entre los representantes de los concejos de Guipúzcoa, uno de cuyos efectos resultantes sería el debilitamien- 
to de su propia organización. Por este motivo no quisieron consentir que cada procurador votara este asunto, sino conseguir un acuerdo por unanimidad. El párrafo es de tal trascendencia que merece la pena acabar el artículo con él:

\begin{abstract}
e aunque por carta patente alguno de los sennores del consejo le enviado a decir que la respuesta que diese la provinçia que non la resçeviese en nonbre de provinçia salvo que cada procurador en nonbre de su consejo diese su voto porque cada uno preçiase el serviçio que fasia en este negoçio por ende que de parte del rey e reyna nuestros sennores les requeria que cada uno de los procuradores que presentes estavan diesen sus votos en nonbre de sus conçejos porque por ellos se viese lo que çerca de la dicha armada la dicha provinçia queria faser lo qual les mandava a cada uno de los dichos procuradores so pena de veynte mill maravedis para la dicha armada e luego los dichos procuradores dixieron que rogavan al dicho liçençiado que non les mandase faser semejante cosa que aquella porque podria ser causa de mayor diferencia e diversidad e que si ellos platicasen primero entresy e se conformasen en sus votos los unos con los otros que mucho mas ayna se faria el dicho serviçio.
\end{abstract}

La respuesta fue prácticamente unánime, tan sólo ha quedado constancia de los reparos expresados por el procurador de la villa de San Sebastián, Martín Sáinz de Estiro, que previamente había llegado a comprometer su patrimonio personal para auxiliar a la formación de la armada en la parte proporcional que tocara a su localidad, pero que quiso constara en el acta su no consentimiento por no contar con el permiso pertinente del concejo que le había elegido como representante. 


\section{APÉNDICE DOCUMENTAL}

1484, enero, 14. Usarraga

Documento escrito que recoge los resultados de la negociación llevada a cabo entre
el licenciado Diego Rodríguez de Baeza y los procuradores de la Provincia
de Guipúzcoa en la Junta celebrada en Usarraga en enero de 1484.

Archivo de la Real Chancillería de Valladolid.

Pleitos civiles. Escribanía Taboada, olvidado, C.L. 34.

En el lugar de Usarraga que es en tierra de Bidania de la muy noble e leal provinçia de Guipuzcoa savado a tres dias del mes de enero anno del nasçimiento del nuestro salvador ihesu xripto de mill e quatroçientos i ochenta e quatro annos estando juntos en junta los honrrados procuradores de los escuderos fijos dalgo de las villas i logares de la dicha noble e leal provinçia de Guipuscoa segund que lo han de uso e de costunbre de se juntar los quales se juntaron para el dicho dia por llamamiento que les fue fecho por el liçençiado Diego Rodrigues de Baeça por virtud de una carta del rey e reyna nuestros sennores e estando asy juntos los dichos procuradores en presençia de mi Domenjon Gonçales de Andia escrivano de camara del rey e reyna nuestros sennores i su notario publico en todos sus regnos i sennorios e escrivano fiel de la noble i leal provinçia e de los testigos de yuso escriptos el dicho liçençiado presento en la dicha junta dos cartas del rey y reyna nuestros sennores: la una firmada de los nonbres de sus altesas e refrendada de su secretario Alonso de Avila e en las espaldas de çiertos nonbres e sellada con su sello e la otra asimesmo de sus nonbres e refrendada del dicho secretario i sennala de una señal las quales dichas cartas asy presentadas por el dicho liçençiado me requirió a mi el dicho Domenjon Gonsales que las abriese e leyese a los dichos procuradores de la dicha junta e las notificase las quales por mi tomadas de verbo a verbum fueron leydas ante los dichos procuradores el thenor de las quales unos en pos de otro es esto que se sigue:

Carta del rey para la Junta (al margen izquierdo)

Don Ferrando e dona Ysabel por la graçia de Dios rey e reyna de Castilla de Leon de Aragon de Çeçilia de Toledo de Valençia de Gallisia de Mallorcas de Sevilla de Çerdenna de Cordova de Corçega de Murçia de Jahen de los Algarves de Algesira de Gibraltar conde e condesa de Barcelona i sennores de Viscaya e de Molina duques de Atenas e de Neopatria condes e Rosellon de de Çerdania marqueses de Oristan e de Goçiano a vos la junta e procuradores de los escuderos fijosdalgo de la nuestra noble i leal provinçia de Guipuscoa i a cada uno de vos salud e graçia. Bien sabedes commo para traer a mas presta conclusión la guerra que nos fasemos al regno e moros de Granada es neçesario que tengamos flota en la mar sobre los puertos della que son del dicho regno de Granada porque non les puedan entrar gente nin mantenimientos e commo que era que fasta aqui avemos tenido nuestra armada guardando el estrecho de Gibraltar e los dichos puertos pero para el anno venidero si a dios ploguiere entendemos cresçer y faser mas poderosa la dicha armada por mas apremiar los dichos moros y para esto avemos menester mas navios y mayores y mas gente de la que fasta qui abemos tenido en la dicha nuestra flota y confiando en la lealtad de vosotros y en 
la avilidad que tiene la gente de la provinçia para las cosas de la mar y que es rason para cosa tan meritoria y loable vosotros seays requeridos y llamados acordamos de enviar alla al liçençiado Diego Rodrigues de Baeça para que de nuestra parte sobre esto falle con vosotros y conçierte el serviçio que para la armada desta flota nos aveys de faser por ende rogamos y mandamosvos que luego vos junteys en junta segund lo aveys de uso e de costunbre e asy juntos con el dicho liçençiado asentéis y conçerteys el tienpo que los navios y gente con que nos aveys de servir para / $1 \mathrm{r}$ la dicha armada y todo lo que con el asentardes y el con vos nos por la presente lo açetamos y loamos y aprovamos y acordamos poder conplido para faser y otorgar todo lo que sobre esto conviniere con todas sus ynçidençias e dependençias y para faser çerca dello los mandamientos e otros avtos que conviniere de lo qual mandamos dar esta nuestra carta firmada de nuestros nonbres e sellada con nuestro sello. Dada en la çibdad de Bitoria a trese dias del mes de desienbre anno del nasçimiento del nuestro sennor ihesu Xripto de mill e quatroçientos e ochenta e tres annos. Va sobre escripto o dis asentéis vala. Yo el rey yo la reyna yo Alfonso de Avila secretario del rey e de la Reyna nuestros sennores la fis escrivir por su mandado en las espaldas acordada Iohanes doctor registrada doctor Pedro de Maluenda chançeller.

El rey y la reyna.

Carta de creençia (al margen izquierdo)

Junta e procuradores de los escuderos fijosdalgo de la nuestra noble e leal provinçia de Guipuscoa nos enbiamos alla al liçençiado de Baeça sobre las cosas que de nuestra parte vos dira y bien somos çiertos que segund vuestra lealtad y el deseo que teneys e a vos mostrado por las obras de nuestro serviçio vos fallaremos bien prestos para esto que queremos que tanto es serviçio de dios y ençalsamiento de su fe y de nuestra corona real e honrra de vosotros y asy vos rogamos e mandamos que le dedes fe y creençia y todo aquello que de nuestra parte vos dixiere pongays por obra segund que de vosotros confiamos y en esto nos fareys señalado serviçio de la çiudad de Bitoria a trese dias de desienbre de ochenta e quatro annos. Yo el rey yo la reyna por mandado del rey e de la reyna. Alfonso de Avila.

Las quales cartas asy presentadas e por mi el dicho Domenjon Gonsales escrivano fiel leydas e notficadas a los dichos procuradores e junta en la manera que dicha es el dicho liçençiado dexados otros razonamientos que fiso que al caso convenian la creençia que dixo que de sus altesas traya para la junta e procuradores començo en la forma seguiente:

Sus reales majestades del rey e reyna nuestros sennores enbian saludes a la junta escuderos fijosdalgo que estays juntos y representays esta noble i leal provinçia de Guipuscoa commo a aquellos que mucho ama e preçian enbian bos decir commo a leales servidores e fieles vasallos en commo bien sabeys y es notorio en estos sus regnos e sennorios con quanta vigilançia solitud e travajo despues que a dios nuestro sennor plugo que ellos veniesen a la subçesion destos regnos han travajado por quantas vias e maneras han podido de estrepar e arredrar todos los males que en ellos abia e redusirlos e traerlos a buena governaçion de justiçia e en quanta pas e sosiego estan oy todos sus subditos e naturales y commo es administrada la justiçia del qual benefiçio gosan todos los tres estados e commo despues que a la divina clemençia plugo dar el tal sosiego quiso conbidar a sus altezas / $1 \mathrm{v}$ a que mas prestamente se moviesen a tomar esta tan sancta e justa enpresa de conquistar el regno de Granada el qual regno fue del sennorio de Espanna poseydo por reyes godos catolicos prinçipes predeçesores de sus reales sennorios donde por luengos tienpos de continuo fue çelebrado el culto divino lo qual todo fue y esta agora profanado e ensusiado de los moros enemigos de nuestra sancta fe catolica donde por ellos es llamado y honrrado el nonbre del malvado mahomad en menospreçio de nuestro salvador Ihesu Xripto e 
de su sancta fe a la qual guerra faser paresçe los dichos sennores rey e reyna por ynçitaçion e amonestaçion divina porque luego ante todas cosas nuestro sennor quiso i permitio que la çiudad de Alama fuese tomada en grande solaçion i quebrantamiento de los dichos moros de lo qual ha subçedido otras muchas e grandes vitorias asy de la presyon del rey de Granada commo de la toma de Sara e otras cosas muy señaladas que han acaesçido donde paresçe que dios muestra aver gana que los dichos moros sean asolados e destruydos e el dicho regno de Granada sea redusido a su sancta fe catolica e ayuntado a estos sus regnos commo antigoamente lo era antes que Espanna fuese destruyda enbian os a decir que a causa de lo suso dicho tiene muy gran gana de conquistar el dicho regno por lo atraer a la union e religion xriptiana non por codiçia nin anbiçion de ensennorear nin atraer asy nin a su subgeçion el dicho regno salvo por serviçio de dios prinçipalmente e acresçentamiento de su sancta fe e porque en sus tienpos e de sus subditos e naturales que agora son se aya de alcançar tan gran gloria e corona e que para faser lo suso dicho es neçesario que poniendo ellos todas las rentas de sus patrimonios reales e avraçandose con el travajo e fatiga de la guerra han querido e quieren continuar lo començado e todo su tienpo espender e gastar en esta sancta enpresa donde creen i tienen que lo que fasta agora çeso de se faser en tienpo de algunos reyes de gloriosa memoria sus projenitores sy por quel tienpo nin aparejo non dio lugar a ello commo por algunos movimientos i escandalos que ovo entonçes en estos sus regnos los quales ynpedieron esta negoçiaçion lo qual todo por la miseraçion divina çesa agora e todo ha suçedido prospera e vitoriosamente e estan quitados e apartados todos los escandalos que podrian ovstar e ynpedir la dicha guerra que sus reales exçelençias non han de çesar nin çesaran fasta seguir el fyn deseado e que para esto todos sus regnos e sennorios han servido e sirven en esta jornada de mucho buena gana tannidos en el amor e fervor que buenos e leales vasallos e servidores han de servir ofresçiendose a resçevir e soportar qualquier carga que les echaren fasiendo la en sy muy ligera y porque para esa negoçiaçion es cosa razonable que se syrva desta noble provinçia pues todos estos regnos han servido y sirven e porque segund la lealtad que esta provinçia tiene en las cosas tocantes a su serviçio non ha seydo ella la postrera e esta provinçia por la graçia de dios abundan en muchos navios e en personas muy guerreras e gentes belicosas e de gran coraçon espeçial en las / 2 r guerras de la mar que sus altezas os enbiar e exortar e demandar que para esta guerra le querays servir con un navio grande de doscientos e çinquenta toneles e con quatro pequennos de cada çient toneles e para el grande que dedes doscientos e çinquenta onbres con su artelleria de guerra i en los otros quatro cada çient onbres asy mismo guarnidos e proveidos a vuestra costa por siete meses los quales comiençen desde primero dia de março deste anno fasta en fyn de setienbre para que esten en el estrecho de Givraltar fasiendo guerra a los moros lo qual confian sus altesas que la provinçia sy fara e conplira commo buenos e leales vasallos espeçialmente para tan sancta e justa tornada e disen sus altezas que aqueste serviçio non lo enviar a demandar a fyn de fatigaros salvo por el caso ser de tal calidad e tan justo e nesçesario por ende que bos ruega e manda que lo asy fagays segund la cofiança de vosotros tiene lo qual todo el dicho liçençiado dixo que desia a los dichos procuradores por virtud de la creençia que de sus reales sennorias traya.

Las quales asy presentadas e rogada la dicha creençia por el dicho liçençiado la dicha junta e procuradores dixieron que obedesçian las dichas cartas presentadas por el dicho liçençiado con aquella reverençia que devian commo a cartas de sus reyes e sennores naturales a quien dios dexase bevir e reynar por muchos tienpos e buenos con maiores regnos e sennorios e quanto al conplimiento dellas e de lo contenido en la dicha creençia dicho por el dicho liçençiado que rogavan al dicho liçençiado que se saliese de la dicha junta e los dexase platicar çerca de todo ello e que ellos darian su 
respuesta testigos Pero Martines de Ygueldo vesino de San Sabastian e Rodrigo Ruys de Leyçaran morador en la dicha tierra de Vidania e Andres de las Risas criado del dicho liçençiado.

E despues de los suso dicho en el dicho logar de Usarraga este dicho dia mes e anno suso dicho dende a poca de hora la dicha junta e procuradores enviar a llamar al dicho liçençiado el qual venido luego yo el dicho Domenjon Gonsales escrivano de camara del rey e reyna nuestros sennores e escrivano fiel desta provinçia por mandamiento de la dicha junta dixe en nonbre de la dicha provinçia e procuradores al dicho liçençiado que los dichos procuradores avian avido su acuerdo e por quanto lo contenido en la dicha creençia era cosa que se avia de platicar con los conçejos al tienpo quel llamamiento fue fecho non fueron informados nin estavan de cosa ninguna de lo contenido en la dicha creençia por ende que le rogavan que por quanto cumplía asy a serviçio de dios nuestro sennor e de los dichos rey e reyna nuestros sennores e al byen desta negoçiaçion que los dichos conçejos fuesen consultados quel dicho liçençiado diese logar e termino convenible para que de lo suso dicho fuesen çertificados los dichos conçejos pero que commo quiera que esto asy fuese que la dicha provinçia se quexava de algunas syn rasones que ella resçivia i avia resçevido por que algunos vesinos onbres onrrados de aquesta provinçia so color desiendo que eran / 2 v logreros los avia enplazado el fiscal para delante sus altezas syn querellante asy mesmo que esta provinçia estava en mengoa de pan e que del Andalucía non se les queria dar saca para lo que ellos oviesen nesçesario para su mantenimiento de lo qual venia grand dapno a la dicha provinçia por que a causa de lo suso dicho valia una fanega de pan un floryn doro e asymesmo que a causa de los puercos que Juan de Sepulveda seyendo corregidor avia represado de un vesino de Navarra estavan presos çiertos vesinos desta provinçia en el dicho regno de Navarra e tomada la recoa i les avia vendido sus mulos i bienes e el dicho liçençiado dixo que commo quier que a el se le fasia grave aver de esperar por la respuesta de los conçejos pero que por onrra de la provinçia e de los procuradores que estavan en la dicha junta que a el le plasia de dar logar a la dicha dilación e que les dava de termino fasta el dia de los reyes que algunos de los dichos procuradores fuesen a estar con sus conçejos e platicar con ellos çerca de lo suso dicho e que les mandava so las mesmas penas del dicho llamamiento primero que para el dicho dia de los reyes se tornasen a juntar aqui en este dicho logar por manera que para otro dia despues de la dicha fiesta le oviesen de dar la respuesta e en lo que toca a las quexas e syn rasones que disen que resçive que bien creya el dicho liçençiado que agravio ninguno non les seria fecho a la dicha provinçia e seyendo sus altesas certificados de lo tal que ellos le remediarian commo cunple a su serviçio e al bien de la dicha provinçia. Testigos los suso dichos.

E despues desto en el dicho logar de Usarraga miércoles siete dias del dicho mes e anno suso dichos en presençia de mi el dicho Domenjon Gonsales escrivano fiel suso dicho e de los testigos de yuso escriptos estando juntos los dichos procuradores en junta para dar la respuesta al dicho liçençiado çerca de lo contenido en las dichas cartas e creençia e queriendo notificarle lo que çerca de lo suso dicho respondian los dichos conçejos luego el dicho liçençiado ante todas cosas dixo que bien sabian commo el avia venido a esta provinçia e presentado çiertas cartas de sus altezas he dicho çierta creençia çerca de la armada que a esta provinçia se mandava faser sobre lo qual los dichos procuradores avyan ydo a platicar con sus conçejos e que bien creya el e aun sabia que en la respuesta avia diversidades e porque el non queria nin conplia a serviçio de sus altesas nin al bien de la provinçia salvo que oviese conformidad e por quel dicho liçençiado avia enbiado a la corte a sus altezas para que le fuese fecha relaçion de lo contenido e respondido por la dicha provinçia al tiempo quel notifico las dichas cartas e el dicho liçençiado avia escripto largo al sennor doctor de Alcocer 
del consejo de sus altezas para que con sus reales sennorias consultase lo contenido en la dicha respuesta i le respondiese e el dicho sennor doctor le avia enviado una carta en la qual se contenian çiertos capitulos / $3 \mathrm{r}$ de los quales los que fasian al caso leyo a los dichos procuradores en la forma seguiente:

Desis que se quexan desiendo que resçiven agravio por que llaman aca a pedimiento del fiscal a algunos vesinos desta provinçia por logreros ellos saben muy vien y aun vos sennor saveys quanto este pecado es avorresçible a dios y dapnoso a los proximos y quanto esa tierra esta infamada dello y fasen a sus altezas conçiençia sus confesores y otros religiosos por que estando aqui tan çerca non paguen este pecado y sobre esto despues de muchas platicas y consyderando sus altezas que las penas desto en quanto a lo pasado se comutan bien en los gastos desta guerra y porque sus altesas quieren bien a toda esta gente y muchos de sus servidores que aca estamos somos afeçionados a esa noble gente plase a sus altezas que esa provinçia de quatro naos con quatroçientos onbres y que de la costa desto paguen lo que son culpantes en el biçio de los logros una buena suma qual vos sennor bierdes con esos buenos de la junta que deven pagar y con esto sus altezas les daran perdon de las penas dello quanto a los pasado con tanto que se obliguen y juren y prometan de non incurrir mas en este pecado de aqui adelante y esto vos negoçiadlo alla que sus altezas lo cunpliran aca por les faser merçed y con esto çesaran los proçesos de aca en estruyendolo vos.

Quanto a la saca del pan que piden a sus altezas plase de les mandar dar alguna saca razonable y para esto en bien persona que lo soliçite y toviera carta sobre el conçierto fecho dalla.

Quanto a los onvres que estan presos en navarra esto ha quedado porque ha dias que non ha estao aqui soliçitador para aquexar a Juan de Sepulveda que es el debdor desto deve venir alguno que entienda en ello.

Determinadamente aveys de negoçiar que sean quatro naos con quatroçientos onvres porque aun los dos dellos bien se pagaran de las penas de los logreros. E asy podeys alla presto despachar pues de aca se faze tan bien cosa noble gente.

Los quales dichos capitulos de la dicha carta asy leydos el dicho liçençiado dixo que mirasen los dichos procuradores coan begnina e humanamente sus altesas avian mirado e respondido en todo lo tocante a la dicha provinçia e que pues sus altesas asy lo miravan e avian querido en lo de la represaria de navarra sus reales sennorias respondian lo contenido en los dichos capitulos que ellos asy commo buenos e fieles vasallos syn aver otro acuerdo nin otra deliberación debian de faser el dicho serviçio el qual partido en dos partes cabia a la dicha provinçia solos dos navios e que en esto rehusaba de faser que non daria buena cuenta a dios nin al mundo pues este negoçio en tantas maneras se justificava e quel dicho liçençiado asy ge lo requeria de parte de sus altesas e luego los dichos procuradores dixieron que avian oydo lo quel dicho liçençiado avia dicho e notificado e que le rogavan que el los dexase platicar / $3 \mathrm{v}$ en el dicho negoçio e que para mannana jueves en otra junta darian la respuesta e el dicho liçençiado dixo que le plasia testigos los dichos.

E despues desto en la dicha Usarraga jueves a ocho dias del mes e anno suso dichos en presençia de mi el dicho Domenjon Gonsales e de los testigos de juso escriptos estando juntos los procuradores de las dichas villas e logares segund que lo han de uso e de costunbre enbiaron a llamar al dicho liçençiado de Baeça para le dar la respuesta e venido el dicho liçençiado e estando junto con los dichos procuradores los dichos procuradores dixieron a Lope Martines Dolaverria procurador de la villa de Segura que en nonbre de la dicha provinçia le diese la respuesta al dicho liçençiado El qual Lope Martines de liçençia e mandamiento de los dichos procuradores fablando con el dicho liçençiado dixo que la junta e procuradores que alli estavan en nonbre de la dicha provinçia avian mucho platicado en aquello quel dicho liçençiado nuevamente 
les avia dicho e fablado çerca de la dicha armada e porque ellos querian travajar mucho commo este serviçio que se oviese de faser se fisiese mas a placer de sus pueblos porque commo eran muchos e diversos avian muchas opiniones entre ellos e para comunicar todo lo que aqui se avia platicado era menester yr a estar con sus conçejos por ende que le pedia de merçed e le rogavan que diese logar a que ellos fuesen o enviasen a los dichos conçejos e que ellos serian aqui con la respuesta para el lunes primero e que esto era lo que de parte de los dichos procuradores le era dicho que favlase al dicho liçençiado e luego el dicho liçençiado dixo que se maravillava mucho de los sennores procuradores que estavan juntos averle de dar tal respuesta a cabo de tanto tienpo e commo quiera que otros onvres prinçipales obiese en la provinçia los que alli estaban eran de los mas prinçipales e que pues ellos veyan la demanda ser tanto justa y sancta e catolica y en el caso mas favorable que en el derecho avia por razon del qual non solamente los bienes de los subditos mas de las iglesias se podrian tomar e enajenar e aquesto respondia a fyn de dilatar e non dar conclusyon en el negoçio non mirando las cosas que sus altesas fasian e miravan en favor desta provinçia mas que de ninguna çibdad nin provinçia destos Regnos que el en ninguna manera non podia estar aquí mas porque sus altezas non le avian dado mas plaso para esta contratación de veynte dias los quales eran ya pasados e porque esta negoçiaçion era de tal calidad que con sus reales sennorias se platicaria mejor que de parte de sus altezas i por virtud del mandamiento que tenia i avia presentado en la junta que mandava al bachiller Juan Sanches Delduayen alcalde de sus altezas en esta provinçia e Martín Sayns Destiro procurador de la villa de San Sabastian i al bachiller de Yturraça alcalde de Tolosa e a Iñigo Sayns de Goyas vesino de Ayspeytia e a Juan Sanches / $4 \mathrm{r}$ de Çumeeta procurador de Ayscoytia e a Lope Ferrandes de Çumaya procurador de Çumaya i a Juan de Ugarte procurador de Villafranca que de oy en nueve dias primeros seguientes se presentasen personalmente delante sus altezas a les faser relaçion de todo lo contenido e que non partiesen della syn su liçençiado e mandado so pena de çient mill maravedis a cada uno para ayuda de la dicha armada e de commo lo mandava e requeria dixo que lo pedia por testimonio e luego los dichos procuradores dixieron al dicho liçençiado que la respuesta por ellos dada non fue a fin de dilatar salvo por lo suso dicho por ende que le rogavan muy mucho que quisiese dar logar para que ellos consultasen con sus conçejos lo que dicho avian e asy mesmos que sobreseyese en el mandamiento que agora nuevamente avia echo e que por quanto a causa de los logreros algunos vesinos desta provinçia estavan enplazados por el fiscal que el les alargase el plaso hasta e en tanto que este negoçio se asentase e el dicho liçençiado dixo que commo quiera quel bien veya que esto todo se fasia a fin de alargar e pasar tienpo pero porque non dixiesen quel non queria dar logar a que esta negoçiaçion se platicase e madurase que a el le plasia esperar hasta el lunes primero seguiente e que fuesen todos a sus conçejos e platicasen con ellos e traxiesen asentado el serviçio que avian de faser que era la provinçia dos navios e otros dos los emplazados de cada çient onbres e en lo que tocava al alargar del plaso a los que estavan llamados por el fiscal quel non tenia poder para ello pero que a los que estavan en esta junta por procuradores e entendían en esto esta armada aunquel non tenia poder para lo alargar pero quel les asegurava que durante el tienpo de la junta non les correria el termino a que avian de parecer e que para esto que le diesen por copia los que alli estavan por procuradores e bien asy que se partia del dicho enplasamiento por amor de la dicha junta testigos Petri de Ygueldo vesino de San Sabastian e Rodrigo hermano del bicario de Vidania e Andres de las Risas criado del dicho liçençiado.

Despues desto en la dicha Usarraga martes trese dias del mes de enero del dicho anno en presençia de mi el dicho Domenjon Gonsales e de los testigos de yuso 
escriptos estando juntos los dichos procuradores en junta segund que lo han de uso e de costunbre e estando ende con ellos el dicho liçençiado de Baeça luego el dicho liçençiado dixo que por quanto para oy dicho dia avia quedado que los dichos procuradores viniesen de sus conçejos a dar la respuesta çerca de lo contenido en el mandamiento de sus altezas tocante a la dicha armada e ellos estavan juntos para dar la dicha respuesta e por quanto el avia seydo certificado que algund conçejo de los prinçipales de la provinçia se avya puesto en escandalo desiendo que non seria en que la dicha armada se fisiese syn que les fuese pagado el sueldo e que algunos otros conçejos querian seguir aquel voto puesto que antes estoviesen de buena / $4 \mathrm{v}$ entençion por ende por quel veya ser asy muy conplidero a serviçio de dios nuestro sennor i de sus altezas e al bien de la tierra e aunque por carta patente alguno de los sennores del consejo le enviado a decir que la respuesta que diese la provinçia que non la resçeviese en nonbre de provinçia salvo que cada procurador en nonbre de su consejo diese su voto porque cada uno preçiase el serviçio que fasia en este negoçio por ende que de parte del rey e reyna nuestros sennores les requeria que cada uno de los procuradores que presentes estavan diesen sus votos en nonbre de sus conçejos porque por ellos se viese lo que çerca de la dicha armada la dicha provinçia queria faser lo qual les mandava a cada uno de los dichos procuradores so pena de veynte mill maravedis para la dicha armada e luego los dichos procuradores dixieron que rogavan al dicho liçençiado que non les mandase faser semejante cosa que aquella porque podria ser causa de mayor diferencia e diversidad e que si ellos platicasen primero entresy e se conformasen en sus votos los unos con los otros que mucho mas ayna se faria el dicho serviçio e despues de avidas muchas platicas entre los unos con los otros los dichos procuradores se apartaron para consentir en el dicho negoçio testigos Andres de las Risas criado del dicho liçençiado i San Juan criado de mi el dicho Domenjon Gonsales.

E despues desto este dia e mes e anno suso dichos dende a cabo de rato estando juntos los dichos procuradores con el dicho liçençiado en presençia de mi el dicho Domejon Gonsales e de los testigos de yuso escriptos luego los dichos procuradores mandaron a mi el dicho Domenjon Gonsales que en nonbre de la dicha provinçia yo diese la dicha respuesta al dicho liçençiado çerca del serviçio que la provinçia queria faser en esta armada a sus altezas la qual di en la forma seguiente:

Los honrrados procuradores que aqui estan juntos en nonbre desta noble provinçia de Guipuzcoa responden a vos el sennor liçençiado de Baeça que por mandado de sus altezas venistes a esta dicha provinçia a entender en esta armada que bien sabeys y es notorio en estos regnos quanto esta noble provinçia e los vesinos della han servido a sus altezas asy en los çercos de Burgos e de Toro commo en otras cosas que han ocurrido espeçialmente en la venida de los françeses a Fuenterrabia donde se fisieron muchas e grandes despensas y aun fueron muertos hartos vesinos della e commo quier que mirando lo suso dicho e asy mesmo las esençiones e franquesas e libertades que esta provinçia tiene y los gastos e necesidades que cada dia han ocurrido e ocurren a ella asy de la carestía del pan commo de otras cosas se pudieran justamente escusar de non faser el dicho serviçio pero por que esta noble provinçia i los fidalgos della siempre fueron muy afeçionados y son al serviçio de sus altezas y porque esta negoçiaçion es de tal calidad que todos los católicos e fieles xriptianos son obligados a seguir tan justa enpresa que a la dicha provinçia le plase de servir non con tantos navios commo les son demandados por que la dicha provinçia non lo puede conplir pero que servira con dos navios cada uno de çient onvres por el tienpo contenido / $5 \mathrm{r}$ en el mandamiento de sus altezas con tanto quel dicho liçençiado en nonbre de sus reales sennorias les otorgue las cosas seguientes e les enbien confirmados de sus altezas de todo ello. 
Las cosas que pide la provinçia sobre la armada:

Lo primero por quanto Alonso de Quintanilla segund ha venido a noticia de la provinçia pide un cuento i doscientas mill maravedis tomando por causa quel condado de Viscaya para la armada de los turcos dio otro tanto i aquello es desafueo i que de aquello tal traya fyn i quito de sus altezas e bien asy manden al dicho Alonso alçe mano de otros achaques e albaquias que pide pues non ay querellante.

Lo otro por quanto algunos prinçipales de la provinçia han seydo enplazados por el fiscal deziendo que son usureros en muy grand bilipendio e desonor de la tierra $i$ aun han seydo çertificados que otros muchos seran llamados asy por çedulas privadas commo por otras cabsas sobre este fecho i sobre otros casos que de todos estos bien asy tenga forma el dicho liçençiado çesen eçesto do obiere querellante.

Lo otro por quanto a causa de las divisiones que sus altezas han con algunos regnos estrannos de tienpo aca ha seydo tanta careza de pan que escasamente los ommes pueden bivir en esta provinçia i este mal non solamente ha redundado de lo que dicho es mas aun en mayor grado el bedamiento de la saca que sus altezas pusyeron en sus regnos por ende a los menos sus altezas manden alçar qualquier enbargo que tienen puesto dando lugar que lo puedan traer a la provinçia por mar o por tierra de qualesquier partes de sus regnos.

Yten que por cabsa destos negros puertos que por el corregidor Juan de Sepulveda fueron tomados por tomas dapnos asy por tomas de bienes i personas i han recreçido aun muertes de ommes e se espera segund los prinçipales dello muchos males i ynconbenientes sy con tienpo sus altezas non proveen çerca dello por ende que enesto bien asy sus altezas remedien de forma que mas ynconbenientes dello non se siga e sean pagados los danificados e presos a cabsa desto con todas sus costas.

Lo otro por quanto en algunos de los puertos de los regnos de sus altezas a los vesinos desta provinçia se les fasen asas agravios espeçialmente non les consentiendo aposentarse / $5 \mathrm{v}$ en los dichos puertos que sus altezas manden dar libremente todos sus puertos segund sus predeçesores solian dar i alçar las ynposiçiones que nuevamente son puestos.

Lo otro commo quier que por las leyes que sus altezas fesieron en las Cortes de Toledo esta proveído çerca los preçios pero todabia syn enbaraço de las dichas leyes algunos sennores que tienen puertos en sus regnos usan de su mala costunbre por sacar las fustas de seco para adobar o por fortuna de entrada o sallida o cargar o descargar segund uso e costunbre que sus altezas manden provar de mucho en todo esto por forma que los bien andantes anden libremente segund solian en tiempo de sus predeçesores.

Otrosy que sus altezas pues en semejantes levantadas sienpre se ha usado prover de pan e almazen que agora asy fagan para todo el tienpo que sus altezas piden el dicho pan en manera de sueldo por que lo contrario seria contra las livertades de los fijosdalgo e porque en algunos tienpos que asy han ydo se les ha dado a los prinçipios i despues se fallan burlados que cada e quando se les fallesçiere sy non fueren proveídos commo se debe que puedan venir syn pena alguna.

E esto seyendoles otorgado i conplido que serviran a sus altezas con dos navios de cada çient toneles armados sufiçientemente con gentes e artillerias. Domenjon Gonsales.

La qual dicha respuesta asy dada por mi el dicho Domenjon Gonsales el dicho liçençiado dixo que sus altezas mucho tenian conosçido los grandes serviçios que esta noble provinçia les avia fecho e asy commo a muy leales servidores los mirava et non solamente esto fasian sus altezas mas los sennores del su muy alto consejo conosçiendo ser asy la voluntad de sus reales sennorias e los meresçimientos de los onrrados e nobles desta dicha provinçia qualquier cosa que a mano dellos venia 
tocante a la via de la justiçia se despachava muy presto e aun enesto y en otras cosas les hera fecha mas preheminençia que non a otros ningunos e que puesto que sus altezas oviesen algund conosçimiento de las neçesidades de la dicha provinçia pero por el negoçio ser de tal calidad que asy mismo non ecusavan que non se maravillasen pues para tan Sancto camino commo aqueste sus reales sennorias se ponian en harta neçesydad para lo llegar al cabo que aquella partiçipase con los fidalgos desta provinçia pues sienpre en las coronicas pasadas ovieron renonbre / $6 \mathrm{r}$ los vesinos della e que ellos asy commo estan en nonbre de la dicha provinçia se devieran de tener por muy injuriados e aviltados sy para esta jornada non fueran requeridos espeçialmente seyendo requeridos todos estos regnos e serviendo con tanta gana commo ellos syrven e que quanto al ofresçimiento de serviçio de los dos navios e asy mesmo de las condiçiones que ellos demandan que sy el dicho serviçio se fisiera por entero commo sus altesas lo mandavan que el alguna cosa fesiera çerca de lo contenido en los dichos capitulos pero pues el dicho serviçio non se fasia en la manera suso dicha que el non podia exçeder la forma del mandamiento a el dado pero que el se partiria de manera de mananna e s yria a sus altesas i faria relaçion de todo lo que aca avia pasado e sus reales sennorias remediarian en ello segund biesen cunplia a su serviçio de lo qual todo commo avia pasado en las dichas juntas pidio a mi el dicho Domenjon Gonsales le diese por testimonio e rogo a los presentes que fuesen ello testigos. Testigos el bicario de Bidania e Rodrigo su hermano e Andres de las Risas criado del dicho liçençiado.

E despues desto otro dia seguiente quatorse dias del mes en la dicha Usarraga en junta Martín Sayns Destiro procurador de San Sabastian dixo quel por sy i sus bienes se obligava de pagar la rata parte que al dicho conçejo suya cabia desta armada sy el dicho conçejo non fuese contento desto pero que non podria consentyr en tanto e que asy gelo diese por testimonio. Testigos toda la junta. Yo el dicho Domenjon Gonsales de Andia escrivano fiel de la dicha noble e leal provinçia de Guipuscoa suso dicho fuy presente a todo lo que dicho es en uno con los dichos testigos en la dicha junta e a ruego e pedimiento del conçejo de la dicha villa de Mondragon este testimonio fise escrivir el qual va escripto en estas seys fojas de pliego de papel e en cada foja va una rubrica de los de mi nonbre e por ende fise en este mio signo atal (el signo) en testimonio de verdad.

Domenjon Gonsales (firmado).

Fecha de recepción del artículo: junio de 2009.

Fecha de aceptación y versión final: junio de 2010. 